\title{
Effects of the Magenstrasse and Mill Operation for Obesity on Plasma Plasminogen Activator Inhibitor Type 1, Tissue Plasminogen Activator, Fibrinogen and Insulin
}

\author{
A.R. Carmichaela G. Tate ${ }^{b}$ R.F.G.J . King ${ }^{\text {a H.M. Sue-Ling a D. J ohnston }}{ }^{a}$ \\ ${ }^{a}$ Academic Department of Surgery, b Department of Haematology, Leeds General Infirmary, Leeds, UK
}

\section{Key Words}

Obesity · Fibrinolysis · Fibrinogen · Insulin

\begin{abstract}
Plasminogen activator inhibitor 1 (PAl-1), tissue plasminogen activator (t-PA), fibrinogen and insulin were measured in 43 patients 3 years after they had undergone the Magenstrasse and Mill (MM) procedure and in 43 morbidly obese (MO) patients. Mean plasma PAl-1 was 61 $\mathrm{ng} / \mathrm{ml}$ in the $\mathrm{MO}$ group compared to $30 \mathrm{ng} / \mathrm{ml}$ in the $M M$ group ( $p<0.0001$ ); mean plasma t-PA was $10 \mathrm{ng} / \mathrm{ml}$ in the MO group compared to $7 \mathrm{ng} / \mathrm{ml}$ in the MM group ( $\mathrm{p}<$ 0.001 ). Mean fibrinogen was $3.6 \mathrm{~g} / \mathrm{l}$ in the MO group compared to $3.2 \mathrm{~g} / \mathrm{l}$ in the MM group $(\mathrm{p}<0.05)$. Mean plasma insulin levels were $32 \mathrm{U} / \mathrm{ml}$ in the $\mathrm{MO}$ group compared to $15 \mathrm{U} / \mathrm{ml}$ in the $\mathrm{MM}$ group. These changes suggest that use of the MM procedure may reduce mortality and morbidity from coronary heart disease in these highrisk obese patients.
\end{abstract}

Copyright $\odot 2002$ S. Karger AG, Base

\section{Introduction}

Obesity is associated with decreased fibrinolysis and increased insulin resistance which are well-established risk factors for the development of coronary heart disease
(CHD) [1-4]. It is postulated that by inhibiting endogenous fibrinolysis, an excess of plasminogen activator inhibitor 1 (PAI-1) may facilitate the process of persistent or recurrent microthrombi formation on the luminal surface of arteries, thus promoting the release of clot-associated mitogens and hence accelerating the process of atherosclerosis [1-4]. It has been shown that dietary or pharmacological interventions resulting in weight loss are accompanied by improvement of the fibrinolytic properties of plasma or even a return to normal [5-7]. Weight loss achieved by surgical interventions such as jejuno-ileal bypass in the past and more recently gastric banding has also been associated with improvement in the fibrinolytic activity of plasma $[8,9]$.

Banded gastroplasty is one of the commonest anti-obesity procedures. However, there is an ever-growing list of complications associated with banded gastroplasty, including ulceration of the band into the lumen of the stomach or outwards into the liver and tissue reaction around the band which may give rise to stenosis [10,11]. Gastric bypass has also been shown to be effective as a primary or revisional procedure for the treatment of morbid obesity. However, altered food transit created by gastric bypass has been shown to be associated with the dumping syndrome, diarrhoea and deficiency of micronutrients leading to neurological syndromes [12-14]. Scopinaro et al. [15] developed biliopancreatic diversion, a malabsorptive procedure without a blind loop. In a report of 1,968

\begin{tabular}{ll}
\hline KARGER & ( 2002 S. Karger AG, Basel \\
1424-8832/02/0321-0040\$18.50/0 \\
$\begin{array}{l}\text { Fax +41613061234 } \\
\begin{array}{l}\text { E-Mail karger@karger.ch } \\
\text { www.karger.com }\end{array}\end{array}$ & $\begin{array}{l}\text { Accessible online at: } \\
\text { www.karger.com/journals/pht }\end{array}$
\end{tabular}

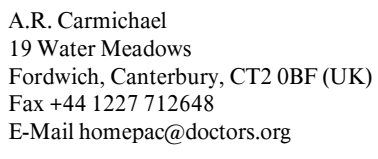


patients (mean age 37 years and mean excess weight $117 \%$ at the time of surgery), at a maximum follow-up of 10 years, the mean excess weight loss was 70\% [15]. The biliopancreatic bypass is not surgically reversible, and is an effective operation for the treatment of the super obese and as a revisional anti-obesity procedure $[16,17]$.

The Magenstrasse and Mill (MM) procedure is a form of anti-obesity operation in which a long narrow gastric tube (the Magenstrasse) is formed around a 32- or 34-FG bougie and the stomach is stapled and divided from the incisura angularis to the angle of His (fig. 1) [18]. The effects of this anti-obesity operation on the fibrinolytic system and insulin are unknown. Therefore, the aim of this study was to determine the effects of the MM procedure for obesity on the fibrinolytic capacity of plasma [measured as plasma PAI-1 and tissue plasminogen activator (t-PA) antigen levels] and on plasma insulin levels.

\section{Patients and Methods}

\section{Patients}

Two groups were studied.

The MM group consisted of 43 patients (37 women) who had undergone the MM procedure at least 12 months before the study. At the time of surgery, their mean \pm SD age was $39 \pm 10$ years and body mass index (BMI) was $47 \pm 7 \mathrm{~kg} / \mathrm{m}^{2}$ (table 1). The blood samples were taken a mean of $3 \pm 1$ years after the MM procedure.

The morbidly obese (MO) group consisted of 43 age- and sexmatched patients (36 women) referred for consideration for anti-obesity surgery who served as obese controls. Their BMI was similar to that of the MM group before operation (table 1).

\section{Collection of Blood Samples and Laboratory Methods}

Venous blood samples were collected after an overnight fast at approximately $9.00 \mathrm{~h}$ after minimum compression of the arm. The first $10 \mathrm{ml}$ were discarded and the next $10-\mathrm{ml}$ sample was taken for analysis of PAI-1 and t-PA in a cold tube containing sodium citrate. The samples were spun at $4^{\circ} \mathrm{C}(1,500 \mathrm{~g})$ for $30 \mathrm{~min}$ within half an hour of the blood being drawn and stored at $-70^{\circ} \mathrm{C}$ until analysed. For analysis of insulin, $5 \mathrm{ml}$ of venous blood was taken in a tube containing EDTA. PAI-1 and t-PA antigen were measured by an enzyme-linked immunosorbent assay (Imulyse ${ }^{\mathrm{TM}} \mathrm{PAI}-1$ and Imulyse ${ }^{\mathrm{TM}}$ t-PA, respectively, from Biopool, Sweden). Plasma insulin was measured by plasma radioimmunoassay (Linco, USA). Fibrinogen was measured by the Clauss technique [19].

\section{Statistical Methods}

All variables are reported as mean \pm SD. Differences between the groups were tested using the Mann-Whitney U test. A p value of 0.05 or less was regarded as statistically significant. Correlations were performed by use of the Spearman test. All statistical analyses were performed by means of a computerised statistical package (GraphPad software ${ }^{\mathrm{TM}}$ ).

Effect of Magenstrasse and Mill Operation on Plasma Fibrinolytic System and Insulin

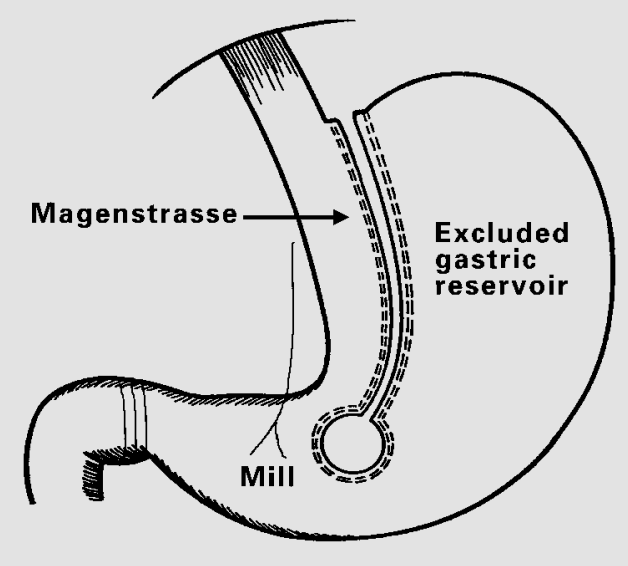

Fig. 1. In the MM procedure, the stomach is stapled vertically and divided from the incisura angularis to the angle of His around a 32to 34-FG bougie. The tube of stomach along the lesser curvature, the 'Magenstrasse', conveys food from the oesophagus to the 'antral mill'. The excluded gastric reservoir drains into the antrum by an orifice approximately $1 \mathrm{~cm}$ wide. The antral mill and the pyloric sphincter are kept intact in order to preserve normal retropulsion, grinding and milling of solid food and well-regulated gastric emptying. No rigid band of foreign material such as Marlex is utilised.

Table 1. Clinical characteristics of patients

\begin{tabular}{llll}
\hline & $\begin{array}{l}\text { MO } \\
\text { group }\end{array}$ & MM group & \\
\cline { 3 - 4 } & & before MM & after MM \\
\hline Number & 43 & 43 & 43 \\
Women:men & $36: 7$ & $37: 6$ & $37: 6$ \\
Age, years & $42 \pm 10$ & $39 \pm 10$ & $41 \pm 10$ \\
BMI, kg/m ${ }^{2}$ & $47 \pm 13$ & $47 \pm 7$ & $33 \pm 6$ \\
\hline
\end{tabular}

No statistically significant difference was found between the MO group and the MM group before surgery.

\section{Results}

\section{Weight}

The weight of the patients in the MM group decreased from $128 \pm 25$ to $88 \pm 19 \mathrm{~kg}$ at a mean follow-up of $3 \pm 1$ years. Mean \pm SD BMI decreased from $47 \pm 7$ to $33 \pm$ $6 \mathrm{~kg} / \mathrm{m}^{2}$. Mean \pm SD excess weight loss was $60 \pm 19 \%$ and excess weight decreased from $68 \pm 21$ to $27 \pm 16 \mathrm{~kg}$. Twenty-nine patients $(66 \%)$ lost more than $50 \%$ of excess 
Table 2. Fibrinolytic variables and insulin in patients

\begin{tabular}{lccl}
\hline & MO group & MM group & $\mathrm{p}$ \\
\hline PAI-1, ng/ml & $61 \pm 29$ & $30 \pm 23$ & $<0.001$ \\
t-PA, ng/ml & $10 \pm 3$ & $7 \pm 4$ & $<0.001$ \\
Fibrinogen, g/1 & $3.6 \pm 0.8$ & $3.2 \pm 0.8$ & $<0.01$ \\
Insulin, U/ml & $32 \pm 18$ & $15 \pm 7$ & $<0.001$ \\
\hline
\end{tabular}

PAI-1 and t-PA levels were significantly lower in the MM group than in the MO group.

body weight and hence were classed as a 'success' in terms of weight loss.

\section{Fibrinolytic System}

All results are summarised in table 2. PAI-1 and t-PA levels were significantly lower in the MM group than in the MO group; a positive correlation was found between BMI and plasma PAI-1 and t-PA concentration (Spearman $r=0.5, p<0.0001$, Spearman $r=0.3, p<0.05$, respectively). Fourteen (32\%) of the MO patients in this study were found to have a t-PA level of more than 12.2 $\mathrm{ng} / \mathrm{ml}$, which is associated with a relative risk of CHD of 2.8 , whereas after the MM procedure, only 4 patients (9\%) had t-PA greater than $12.2 \mathrm{ng} / \mathrm{ml}$. Likewise, only 1 of the MO patients $(2 \%)$ had a t-PA of $<5.2 \mathrm{ng} / \mathrm{ml}$, which is associated with a relative risk of CHD of 1 (i.e. normal), whereas $16(36 \%)$ patients in the MM group had such low levels of t-PA.

Plasma fibrinogen levels were available in 36 patients after the MM procedure and were significantly lower in the MM group compared to the MO group (mean $\pm \mathrm{SD}$ fibrinogen $3.6 \pm 0.8$ and $3.2 \pm 0.8 \mathrm{~g} / \mathrm{l}$, respectively; $\mathrm{p}<$ $0.01)$. Seventeen patients $(49 \%)$ in the MM group had a fibrinogen level of less than or equal to $3 \mathrm{~g} / \mathrm{l}$, while 21 patients $(49 \%)$ in the MO group had a fibrinogen level between 3.1 and $4 \mathrm{~g} / \mathrm{l}$. Only 5 patients (14\%) in the MM group had a fibrinogen level of more than $4 \mathrm{~g} / \mathrm{l}$ as opposed to 13 patients $(30 \%)$ in the $\mathrm{MO}$ group.

\section{Insulin}

Fasting plasma insulin levels were significantly lower in the MM group than in the MO group (MO $32 \pm 18$ $\mathrm{U} / \mathrm{ml}$ vs. MM $15 \pm 7 \mathrm{U} / \mathrm{ml} ; \mathrm{p}<0.001)$. A significant positive correlation was found between plasma insulin and plasma PAI-1 (Spearman $\mathrm{r}=0.5, \mathrm{p}<0.0001$ ) and plasma insulin and BMI (Spearman $\mathrm{r}=0.5, \mathrm{p}<0.001)$.

\section{Discussion}

MO patients who were referred for surgery in our study had markedly elevated levels of the risk factors for CHD such as PAI-1, t-PA and insulin, despite repeated attempts at dieting, exercise and medical treatment. Most patients studied after the MM procedure achieved a considerable weight loss and maintained it throughout a mean follow-up of 3 years after operation. We confirmed that the plasma levels of insulin, PAI-1 and t-PA were positively associated with obesity and found that these levels were significantly lower in patients after surgically induced weight loss. Our results confirm previously reported findings that weight loss achieved by medical or surgical interventions is associated with improvements in the fibrinolytic properties of plasma $[5,8,20]$. We chose to assess PAI-1 and t-PA antigens as indicators of fibrinolysis because they have been shown previously to correlate with obesity, and, in particular, t-PA has been associated with the occurrence of myocardial infarction [21,22].

In our study, a small but statistically significant difference was found in the plasma fibrinogen levels between the MM group and the MO group. Raised fibrinogen levels are thought to increase the risk of CHD in apparently healthy asymptomatic individuals and in patients with peripheral vascular disease [23-26]. However, weight loss after successful treatment of obesity is not always found to be associated with a decline in plasma fibrinogen levels [23].

This was a case-control study and so fibrinolytic factors were not studied in the same patients before and after weight loss, which would have been ideal. However, we feel it is reasonable to attribute the marked normalisation of the PAI-1 and t-PA, levels in the MM group to the surgical treatment of obesity because of large and consistent differences in the levels of PAI-1, t-PA, fibrinogen and insulin between the two groups. Therefore, we conclude that good control of the abnormal fibrinolytic state in obese patients can be achieved by the MM procedure for at least 1-5 years. Whether these beneficial effects will be maintained in the long term remains to be established. 


\section{References}

1 Juhan-Vague I, Vague P: Hypofibrinolysis and insulin-resistance. Diabete Metab 1991;17:96100.

2 Reaven GM: Banting lecture 1988. Role of insulin resistance in human disease. 1988. Diabetes 1997;37:1595-1607.

3 Niewiarowski S, Rao AK: Contribution of thrombogenic factors to the pathogenesis of atherosclerosis. Prog Cardiovasc Dis 1983;26: 197-222.

4 Schwartz CJ, Valente AJ, Kelley JL, Sprague EA, Edwards EH: Thrombosis and the development of atherosclerosis: Rokitansky revisited. Semin Thromb Hemost 1988;14:189195.

5 Andersen T, Astrup A, Quaade F: Dexfenfluramine as adjuvant to a low-calorie formula diet in the treatment of obesity: A randomized clinical trial. Int J Obes Relat Metab Disord 1992;16:35-40.

6 Kockx M, Leenen R, Seidell J, Princen HM, Kooistra T: Relationship between visceral fat and PAI-1 in overweight men and women before and after weight loss. Thromb Haemost 1999;82:1490-1496.

7 Ernst E, Weihmayr T, Matrai A, Resch KL: Changes in blood rheology of grossly obese individuals during a very low calorie diet. Int $\mathrm{J}$ Obes 1989;13(suppl 2):167-168.

8 Primrose JN, Davies JA, Prentice CR, Hughes $\mathrm{R}$, Johnston D: Reduction in factor VII, fibrinogen and plasminogen activator inhibitor-1 activity after surgical treatment of morbid obesity. Thromb Haemost 1992;68.396-399.

9 Sylvan A, Rutegard JN, Janunger KG, Sjolund B, Nilsson TK: Normal plasminogen activator inhibitor levels at long-term follow-up after jejuno-ileal bypass surgery in morbidly obese individuals. Metabolism 1992;41:1370-1372.
10 Sugerman HJ, Kellum JM Jr, DeMaria EJ, Reines HD: Conversion of failed or complicated vertical banded gastroplasty to gastric bypass in morbid obesity. Am J Surg 1996;171: 263-269.

11 MacLean LD, Rhode BM, Forse RA, Nohr R: Surgery for obesity - an update of a randomized trial. Obes Surg 1995;5:145-150.

12 Rhode BM, Tamin H, Gilfix BM, Sampalis JS, Nohr C, MacLean LD: Treatment of vitamin B12 deficiency after gastric surgery for severe obesity. Obes Surg 1995;5:154-158

13 Halverson JD: Micronutrient deficiencies after gastric bypass for morbid obesity. Am Surg 1986;52:594-598.

14 Abarbanel JM, Berginer VM, Osimani A, Solomon H, Charuzi I: Neurologic complications after gastric restriction surgery for morbid obesity. Neurology 1987;37:196-200.

15 Scopinaro N, Gianetta E, Adami GF, Friedman D, Traverso E, Marinari GM, Cuneo S, Vitale B, Ballari F, Colombini M, Baschieri G, Bachi V: Biliopancreatic diversion for obesity at eighteen years. Surgery 1996;119:261-268.

$16 \mathrm{Kral} \mathrm{JG}$ : Overview of surgical techniques for treating obesity. Am J Clin Nutr 1992;55 (suppl 2):552S-555S

17 Summers G, Hocking MP: Surgical approach to the obese patient. J Fla Med Assoc 1992;79: 396-399.

18 Johnston D, Sue-Ling HM: Surgical treatment of morbid obesity; in Cushieri A, Moosa AR, Giles GR (eds): Essential Surgical Practice. London, Butterworth-Heinemann, 1995, pp 1036-1044.
19 Clauss A: Gerinnungsphysiologische Schnellmethode zur Bestimmung des Fibrinogens. Acta Haematol 1957;17:237-240.

20 Ridker PM, Vaughan DE, Stampfer MJ, Manson JE, Hennekens $\mathrm{CH}$ : Endogenous tissuetype plasminogen activator and risk of myocardial infarction. Lancet 1993;341:1165-1168.

21 Vague P, Juhan-Vague I, Aillaud MF, Badier C, Viard R, Alessi MC, Collen D: Correlation between blood fibrinolytic activity, plasminogen activator inhibitor level, plasma insulin level, and relative body weight in normal and obese subjects. Metabolism 1986;35:250-253.

22 Sundell IB, Nilsson TK, Ranby M, Hallmans G, Hellsten G: Fibrinolytic variables are related to age, sex, blood pressure, and body build measurements: A cross-sectional study in Norsjo, Sweden. J Clin Epidemiol 1989;42:719723.

23 Meade TW, North WR, Chakrabarti R, Stirling Y, Haines AP, Thompson SG, Brozovie M: Haemostatic function and cardiovascular death: Early results of a prospective study. Lancet 1980;i:1050-1054.

24 Ernst E, Resch KL: Fibrinogen as a cardiovascular risk factor: A meta-analysis and review of the literature. Ann Intern Med 1993;118:956963.

25 Fowkes FG, Lowe GD, Housley E, Rattray A, Rumley A, Elton RA, MacGregor IR, Dawes J Cross-linked fibrin degradation products, progression of peripheral arterial disease, and risk of coronary heart disease. Lancet 1993;342:8486 .

26 Banerjee AK, Pearson J, Gilliland EL, Goss D, Lewis JD, Stirling Y, Meade TW: A six year prospective study of fibrinogen and other risk factors associated with mortality in stable claudicants. Thromb Haemost 1992;68:261-263. 